PUBLIC OPINION POLLING AND POLITICS IN BRITAIN 


\section{CONTEMPORARY POLITICAL STUDIES SERIES}

Series Editor: John Benyon, Director, Centre for the Study of Public Order, University of Leicester

A series which provides authoritative yet concise introductory accounts of key topics in contemporary political studies.

Other titles in the series include:

UK Political Parties since 1945

Edited by ANTHONY SELDON, Institute of Contemporary British

History

Politics and Policy Making in Northern Ireland MICHAEL CONNOLLY, University of Ulster

Local Government and Politics in Britain JOHN KINGDOM, Sheffield Polytechnic

British Political Ideologies

ROBert LeACH, Leeds Polytechnic

British Government: The Central Executive Territory PETER MADGWICK, Professor Emeritus, Oxford Polytechnic

Race and Politics in Britain

SHAMIT SAGGAR, Queen Mary and Westfield College, University of London

Selecting the Party Leader

MALCOLM PUNNETT, University of Strathclyde

Does Parliament Matter?

PHILIP NORTON, University of Hull

The President of the United States

DAVID MERVIN, University of Warwick

The Politics of Economic Policy

WYN GRANT, University of Warwick

Introduction to International Politics

DEREK HEATER, formerly of Brighton University and

G. R. BERRIDGE, University of Leicester

Elections and Voting Behaviour in Britain (2nd Edition)

DAVID DENVER, Lancaster University

The Law and Politics of the British Constitution

PETER MADGWICK and DIANA WOODHOUSE, Oxford Brookes University

Pressure Groups, Politics and Democracy in Britain (2nd Edition)

WYN GRANT, University of Warwick 


\title{
PUBLIC OPINION POLLING AND POLITICS IN BRITAIN
}

\author{
DAVID BROUGHTON \\ School of European Studies, \\ University of Wales College of Cardiff
}

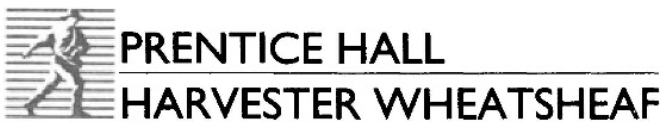

London New York Toronto Sydney Tokyo Singapore Madrid Mexico City Munich 


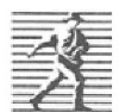

First published 1995 by

Harvester Wheatsheaf

Campus 400, Maylands Avenue

Hemel Hempstead

Hertfordshire, HP2 7EZ

A division of

Simon \& Schuster International Group

(C) David Broughton, 1995

All rights reserved. No part of this publication may be reproduced, stored in a retrieval system, or transmitted, in any form, or by any means, electronic, mechanical, photocopying, recording or otherwise, without prior permission, in writing, from the publisher.

Typeset in 10/12pt Times

by Dorwyn Ltd, Rowlands Castle, Hants.

Library of Congress Cataloging in Publication Data

Broughton, David, 1957-

Public opinion polling and politics in Britain/David Broughton.

p. cm. - (Contemporary political studies series)

Includes bibliographical references and index.

ISBN 978-0-333-73916-7

1. Public opinion-Great Britain. 2. Great Britain-Politics and government-1979-Public opinion. 3. Public opinion polls.

I. Title. II. Series.

HN400.P8B76 1995

303.3'8'0941-dc20

95-10435

CIP

British Library Cataloguing in Publication Data

A catalogue record for this book is available from the British Library

ISBN 978-0-333-73916-7

ISBN 978-1-349-14907-0 (eBook)

DOI 10.1007/978-1-349-14907-0 


\section{CONTENTS}

List of tables

Preface vii

I The history of opinion polling in Britain I

2 The assumptions and theory of public opinion polling 15

3 The methodology of opinion polling 34

4 The use and impact of national opinion polling 84

5 The use and impact of sub- and supra-national opinion
polling

6 The opinion polls and political issues 151

$\begin{array}{ll}7 \text { Conclusion } & 193\end{array}$

\section{APPENDICES}

I Glossary of technical terms used in polling 202

$\begin{array}{ll}\text { II Sample questions taken from polls } & 213\end{array}$

$\begin{array}{ll}\text { III The polling experience } & 220\end{array}$

General bibliography $\quad 222$

Index 226 


\section{TABLES}

1.1 The five main political polling firms 2

3.1 The main advantages and disadvantages of different 71 data collection methods

3.2 A frequency distribution of strength of identification with 75 the Labour Party by Labour Party members, 1989-90

3.3 A cross-tabulation of occupation by trade union or 76 staff association membership

4.1 The final polls and actual election results, 1970-92 86

5.1 A comparison of exit poll and actual by-election 133 results in selected constituencies

6.1 Attitudes to British membership of the European 161 Community

6.2 Attitudes to trade unions, 1952-94 


\section{PREFACE}

A book on the theme of public opinion polling and politics in Britain seems particularly apposite in the wake of the general election of April 1992. Inevitably, the 'failure' of the polls to predict correctly an overall majority of twenty-one seats for the Conservative Party has engendered widespread criticism aimed at the use of polls in general as well as their specific value for observers and practitioners of politics alike.

This criticism derives at least in part from the apparently unstoppable growth in the number of polls commissioned and the obsessive poring over the results in the media to the virtual exclusion of alternative sources of information. Additionally, the increase in the number of polls throughout the 1980s was not accompanied by either a broader or a deeper understanding of what opinion polls can and do achieve and what challenges lie ahead for them in the future. The 'classic' textbook on polling in Britain remains Teer and Spence's Political Opinion Polls, published more than twenty years ago in 1973.

This lack of comprehension of the finer nuances of polling has not prevented many newspapers, even the tabloid press, from basing more and more stories on polling data. The range of "poll stories' is enormous, covering topics such as who are the happiest people in the world (the inhabitants of Guernsey) and survey assessments of the impact of violence on television on the behaviour of ordinary people. A regular obsession of the tabloid press in 
particular is 'sex surveys', one of which produced the sober conclusion that 'lust is difficult to measure'.

The degree to which polls provide stories which newspapers will print can be exemplified by page 4 of the Daily Telegraph on 31 December 1987. On that day, three separate stories were drawn from polls. The first was based on a Gallup poll whose headline read " "Glasnost" failing to make impact on most Russians'. This poll was conducted in thirty-seven countries in all, and countries were classified by the degree to which their populations were 'optimistic' or 'pessimistic' about prospects for 1988 compared to the previous year. It included the first interviews by Gallup in the Soviet Union.

The second story on that day informed readers that 'women in the West are happier than men.' This conclusion was based on a comparative study of the quality of life experienced by people in the United States and the member states of the European Community. Cultural factors were deemed to influence the way that different people in different countries answer when asked about their personal happiness or unhappiness.

The third story told readers that Sir Francis Drake was believed by some children aged between 8 and 14 to be a well-known cricketer. This was part of a poll dealing with basic historical events and people which also examined familiarity with the Spanish Armada and the significance of the date 1066. In the poll, seven out of ten children knew that Guy Fawkes had attempted to blow up the Houses of Parliament. Touchingly, one individual child believed that Guy Fawkes had 'travelled the country organising firework displays'.

The purpose of this book is more specific: namely, to analyse the functions and use of opinion polling and its impact on politics in Britain. In particular, the criticisms of the role and performance of opinion polls during the 1992 general election will be considered.

The first chapter of the book briefly sets out the history of polling in Britain, including the roots of present polling practices and the latest developments in the conduct of polls since 1979. The second chapter discusses the assumptions and theories on which modern polling is based, in particular the dimensions of public opinion and the composition of the 'public' as well as the criticisms of polls as a means of establishing the contours of public opinion.

The methodology of polling is described in chapter 3 , comprising the procedures and problems associated with questionnaire 
design, sampling, interviewing and data collection, the interpretation of the data and the presentation of the final results. The next two chapters are linked: chapter 4 looks at the use of polling by those most closely involved in the conduct of national British politics, namely, the electorate, the government, political parties, the mass media and pressure groups; chapter 5 looks at the use and impact of polling both below and above national level, encompassing by-election polls, constituency polls, polls conducted in marginal seats and local and European election polls.

The ways in which the polls attempt to measure the importance and impact of issues in British politics are analysed in chapter 6 by means of considering five specific issues (the European Community, trade unions and industrial relations, immigration and race relations, the environment and electoral reform). The concluding chapter of the book brings together the various strands of the previous chapters in an assessment of the importance of polling in British politics and its likely role in the future.

The book mainly deals with opinion polls and the problems of opinion polling in Britain, but in places it also touches on wider questions of survey research in general. For much of the book, the problems and challenges facing polls and surveys are similar and in those sections, polls and surveys are taken together. Distinctions between polls and surveys are often little more than matters of greater detail and length in the latter although there is sometimes more than a whiff of academic snobbery when survey specialists are commenting upon and using poll data.

There are inevitably a large number of intellectual debts which have to be acknowledged in a book of this sort. Particular encouragement throughout the extended process of writing was received from John Benyon and David Denver as well as Clare Grist of Harvester Wheatsheaf, who displayed great patience in the face of a number of enforced delays in completing the book.

The book has benefited enormously from conversations with pollsters, party officials and media representatives who often gave freely of their time as well as providing much information. My grateful thanks to the following must therefore be expressed:

Pollsters: Bob Wybrow (Gallup), Robert Waller and John Hanvey (Harris), Nick Sparrow (ICM), Bob Worcester, Brian 
Gosschalk and Simon Braunholtz (MORI), Nick Moon (NOP). Bob Wybrow was especially helpful in supplying Gallup data which forms the basis of much of chapter 6 and Bob Worcester allowed me to read and use the private MORI reports to the Labour Party.

Party officials: Rex Osborn (Labour Party), Keith Britto (Conservative Party) and Chris Rennard (Liberal Democrats).

Media: David Cowling (ITN) and David McKie (Guardian).

Others who provided help at various stages were Sir Thomas Arnold MP (Conservative), Geoffrey Hiscocks (Beaufort Research, Cardiff), Lesley Sopp (Consumers Association), Colin Francome, Denis Balsom and Ian McAllister.

Karen Owen typed much of the final manuscript with her usual unflappable calmness and care. Great support was received from Professor David Hanley as Head of the School of European Studies at the University of Wales in Cardiff as well as various colleagues in EUROS who either read draft chapters or encouraged me in other ways. In that context, particular thanks are due to Peter Dorey and Mark Donovan.

All of the above are of course absolved from any responsibility for the interpretation that follows. The errors that remain cannot honestly be ascribed to either sampling error or questionnaire design - they are, however, equally inevitable.

This book is dedicated to two people: firstly, to my late father, Jim Broughton, and secondly, to my niece, Ameenah. They have both influenced the writing of this book in very different but equally vital ways. 